\title{
PLASMA AND ERYTHROCYTE LEVELS OF TRACE ELEMENTS IN HEALTHY ELDERLY
}

\author{
Todorova V., P. Tchankova, V. Madjova* \\ Department of Internal Diseases, Department of Family Medicine*, \\ Medical University, Varna, Bulgaria
}

Reviewed by: Assoc. Prof. V. Ikonomov, MD, PhD

\section{SUMMARY}

The purpose of the investigation was an assessment of $\mathrm{Mg}, \mathrm{Zn}$ and $\mathrm{Cu}$ in plasma and erythrocytes of healthy elderly. The examined subjects were: 20 old over 80 years and a control group of 32 healthy individuals under 60 years. The levels of trace elements were measured with atomic absorption spectrophotometry (AAS - 3030 B Perkin Elmer spectrophotometer). The data showed normal plasma and erythrocyte concentrations of $\mathrm{Mg}$ in healthy elderly. Plasma $\mathrm{Cu}$ level indicated an elevation, while intraerythrocytic $\mathrm{Cu}$ showed the opposite tendency of significant decreasing in the group over 80 years $(\mathbf{8 0 - 8 9}$ years) in comparison to controls $(11,35$ $\pm 5,30 \mu \mathrm{mol} / \mathrm{l}$ vs $16,75 \pm 5,60 \mu \mathrm{mol} / \mathrm{l})$. Plasma $\mathrm{Zn}$ was in normal limits with a slight tendency of decreasing, while RBC Zn was significantly lower in both elderly groups in comparison to controls: in 80-89 years pts $158,14 \pm 43,79 \mu \mathrm{mol} / \mathrm{l}$ and in $90-102$ years pts $-150,00 \pm 23,85 \mu \mathrm{mol} / \mathrm{l}$ vs $230,70 \pm 51,39 \mu \mathrm{mol} / \mathrm{l}$ in the controls. Our data showed that the estimation of intraerythrocytic levels of $\mathrm{Cu}, \mathrm{Zn}$ and $\mathrm{Mg}$ gives us a more important information for their actual status and indicates a deficiency of $\mathrm{Cu}$ and $\mathrm{Zn}$ in old subjects. We recommend food enrichment with $\mathrm{Zn}$ even in healthy elderly individuals.

Abbreviations: copper $(\mathrm{Cu})$, erythrocytes $(\mathrm{RBC})$, magnesium $(\mathrm{Mg})$, zinc $(\mathrm{Zn}) \mathrm{KEY}$

Keywords: copper, elderly, erythrocytes (RBC), plasma, magnesium, zinc

\section{INTRODUCTION}

The role of trace elements in the process of aging is not completely revealed. One of the components of the antioxidant system includes zinc $(\mathrm{Zn})$ and copper $(\mathrm{Cu})$ as ingredients of the enzyme superoxide dismutase (SOD) and this proposes participation of these elements in aging. Man's immune system, the action of some hormones and over 200 enzymes are $\mathrm{Zn}$-dependent. The insufficient $\mathrm{Cu}$ also reflects mainly on the cells and causes predominantly hematological disturbances connected with the reduced activity of Cu-containing enzymes $(1,2)$.

Magnesium $(\mathrm{Mg})$ is an important intracellular ion, which activates a large number of enzymes, acts in the regulation of energy metabolism and in supporting $\mathrm{K} / \mathrm{Na}$ membrane gradient. The development and progression of atherosclerosis, hypertension, heart and psychological disturbances and osteoporosis in $\mathrm{Mg}$ - deficiency opens the question of

\footnotetext{
Address for correspondence:

Valentina Madjova, MD, PhD, Associate Professor, Department of Family Medicine, Medical University, Varna, bld "Christo Smirnensky" No 1

e-mai:v_madjoy@abv.bg
}

the possible role of this trace - element in the aging process for discussion (3).

More significant information can be obtained for the active status of these elements in examination their red blood cell (RBC) concentrations rather than their levels in plasma. Possibly this is due to the fact that they take part in the enzyme processes on molecular and cellular level. Sometimes, if we ignore their important role and examine their plasma concentration only, we should conclude facts that are controversial to their active intracellular status.

\section{AIM OF THE STUDY}

The aim of the study is to examine the concentrations of $\mathrm{Mg}$, $\mathrm{Cu}$ and $\mathrm{Zn}$ in plasma and erythrocytes in healthy elderly individuals over 80 years and their changes with aging.

\section{SUBJECTS AND METHOD}

We examined the concentration of $\mathrm{Mg}, \mathrm{Cu}$ and $\mathrm{Zn}$ in plasma and $\mathrm{RBC}$ in 20 elderly individuals $(\mathrm{n}=20,7$ men and 13 women), age 80 - 102 years (tabl.1), living in a nursing home without data for renal diseases, hypertension, diabetes mellitus and hypercholesterolemia. The results were 
compared to plasma of a control group of clinically healthy

Tabl. 1. Demographic data of our studies

\begin{tabular}{||c|c|c|c||}
\hline \hline \multirow{2}{*}{} & \multicolumn{2}{|c|}{ Age (years) } & \multirow{2}{*}{$\begin{array}{c}\text { Number of } \\
\text { patients }\end{array}$} \\
\cline { 2 - 4 } & Range & $\mathrm{X} \pm \mathrm{SD}$ & 10 \\
\hline Group B & $80-89$ & $85.7 \pm 2.4$ & 10 \\
\hline Group C & $90-102$ & $92.0 \pm 3.4$ & 10 \\
\hline \hline
\end{tabular}

subjects, age 20-60 years (4).

$\mathrm{Mg}, \mathrm{Cu}$ and $\mathrm{Zn}$ in both, plasma and $\mathrm{RBC}$ were measured with atomic absorption spectrophotometer AAS - 3030 B Perkin Elmer $(5,6)$. Variation analysis $(\mathrm{x} \pm \mathrm{SD})$ was applied for statistical data processing. The results were assessed with t-coefficient of Student - Fischer with statistical significant value $\mathrm{p}<0.05$.

\section{RESULTS}

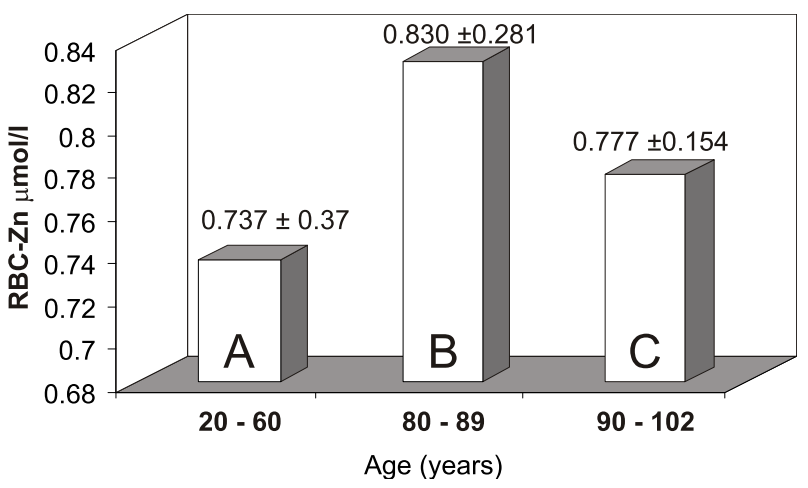

Fig. 1. RBC-Zn concentrations are compared between two groups elderly patients ( $B$ and $C$ ) and control group young patients (A). Values are given as mean \pm standard deviation. Significant diferences were assumed if $p<0.05$. $* P<0.05-B, C: A$

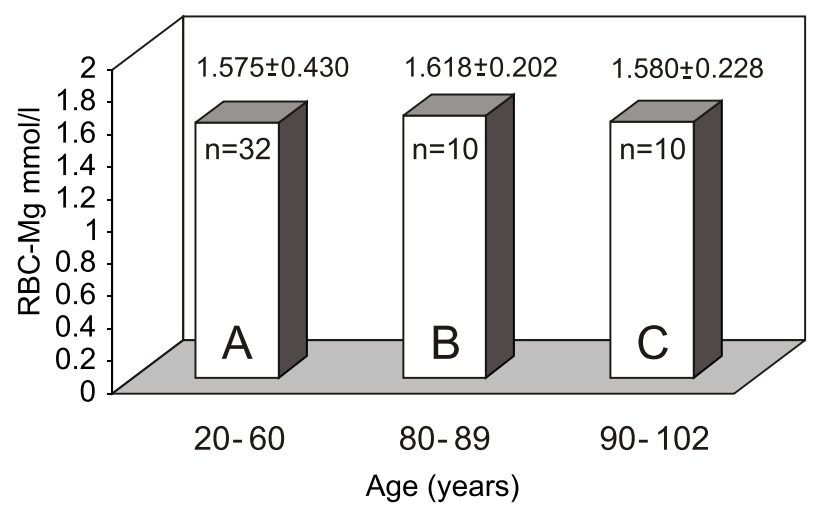

Fig. 2. RBC-Mg concentrations are compared between two groups elderly patients ( $B$ and $C$ ) and control group young patients (A). Values are given as mean \pm standard deviation. Significant diferences were assumed if $p<0.05 . P-N S e$
MAGNESIUM - We didn't find statistically significant differences in plasma $\mathrm{Mg}$, either between the two groups of elderly individuals: $80-89$ years $(0,830 \pm 0,281 \mathrm{mmol} / \mathrm{l})$ and 90 -102 years $(0,777 \pm 0,154 \mathrm{mmol} / \mathrm{l})$ or in the control group 20-60 years $(0,737 \pm 0,37 \mathrm{mmol} / 1)$ (fig. 1$)$.

RBC Mg didn't show significant changes with aging, resp. control group 20-60 years $(1,575 \pm 0,43 \mathrm{mmol} / 1)$; $80-89$ years $(1,818 \pm 0,266 \mathrm{mmol} / \mathrm{l}) ; 90-102$ years $(1,580 \pm 0,228$ $\mathrm{mmol} / \mathrm{l}$ ) (fig.2).

COPPER - Plasma $\mathrm{Cu}$ increased with the age. The change was significant for the age group $>90$ years in comparison to controls $<60$ years, resp. $19.44 \pm 3,31 \mu \mathrm{mol} / 1$ and 15,30 $\pm 3,12 \mu \mathrm{mol} / 1$ (fig.3).

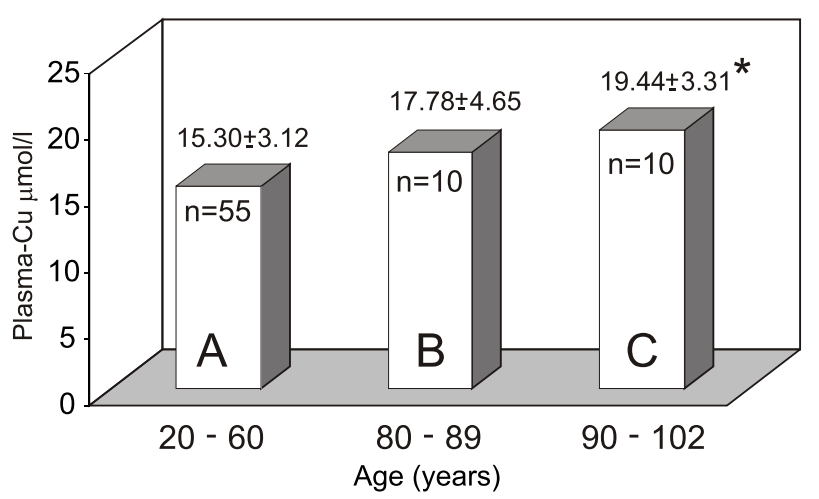

fig. 3. Plasma-Cu concentrations are compared between two groups elderly patients ( $B$ and $C$ ) and control group young patients (A). Values are given as mean \pm standard deviation. Significant differences were assumed if $p<0.05 * P<0.05 C: A$

RBC Cu showed a tendency towards decreasing with aging. The difference was significant for the age group 80-89 years in comparison to controls, resp. $11,35 \pm 5,30 \mu \mathrm{mol} / 1$ vs $16,75 \pm 5.60 \mu \mathrm{mol} / \mathrm{l}$ (fig.4),

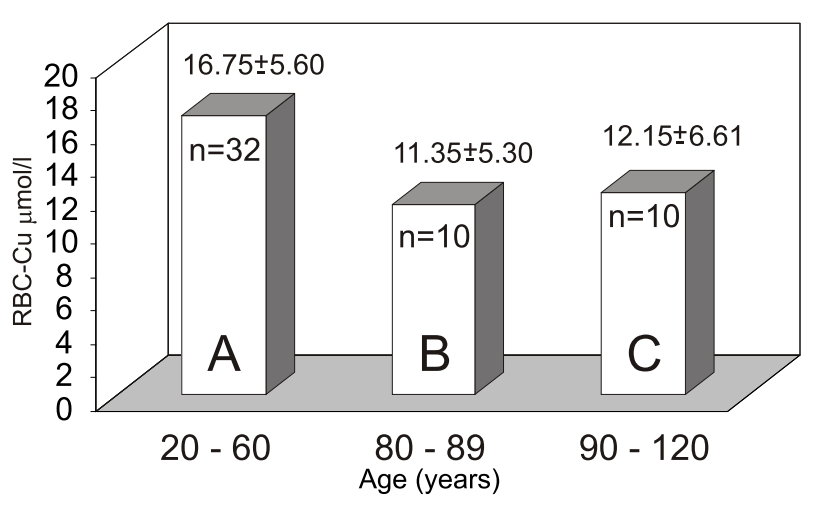

Fig. 4. RBC-Cu concentrations are compared between two groups elderly patients ( $B$ and $C$ ) and control group young patients (A). Values are given as mean \pm standard deviation. Significant diferences were assumed if $p<0.05 . * P<0.05-B: A$

ZINC - Plasma $\mathrm{Zn}$ in both group elderly was decreased compared to the controls, but the difference was not statistically significant (fig.5). 
RBC Zn was significant decreased in elderly individuals >80 years: $80-89$ years $(158,14 \pm 43,79 \mu \mathrm{mol} / 1)$; $90-102$ years $(150,00 \pm 23,85 \mu \mathrm{mol} / \mathrm{l})$ in comparison to controls $(230,70 \pm 51,39 \mu \mathrm{mol} / \mathrm{l})$. There was not a significant difference in RBC between the two groups of elderly 80-89 and 90-102 years (fig.6).

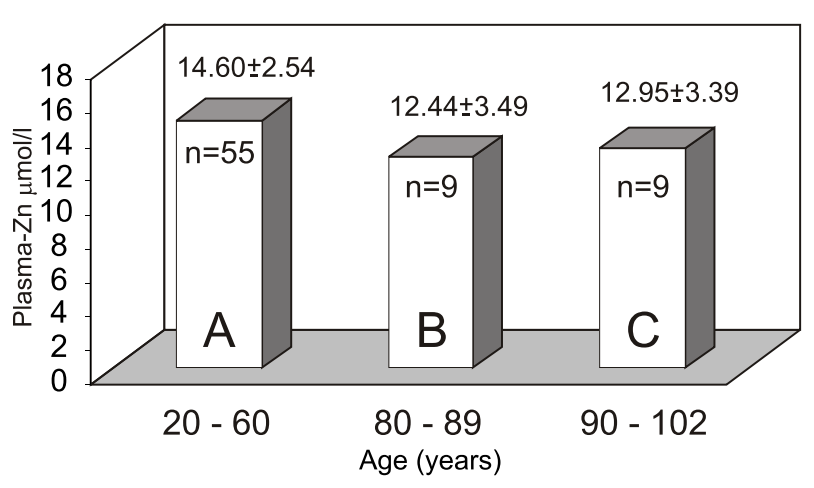

Fig. 5. Plasma-Zn concentrations are compared between two groups elderly patients ( $B$ and $C$ ) and control group young patients (A). Values are given as mean \pm standard deviation. Significant diferences were assumed if $p<0.05$. $P-N S$

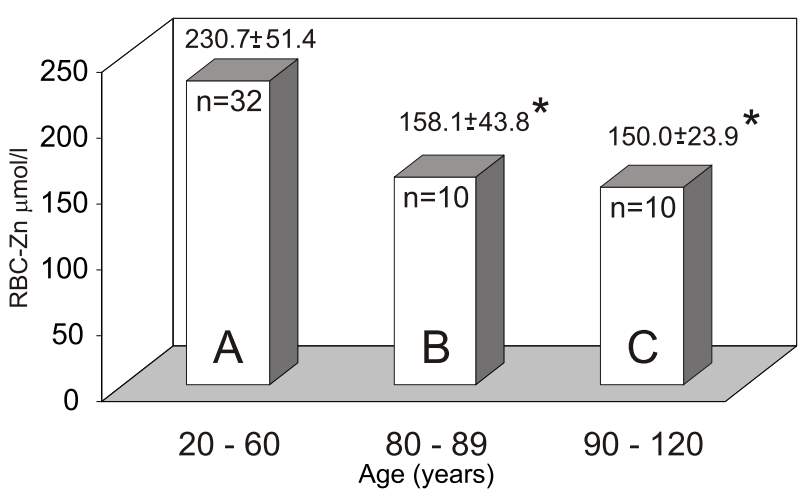

Fig. 6. RBC-Zn concentrations are compared between two groups elderly patients ( $B$ and $C$ ) and control group young patients (A). Values are given as mean \pm standard deviation. Significant diferences were assumed if $p<0.05$. $* P<0.05-B, C: A$

\section{DISCUSSION}

The examination of $\mathrm{Cu}, \mathrm{Zn}$ and $\mathrm{Mg}$ plasma concentrations in healthy elderly individuals gives the opportunity for assessment if the aging has an influence on the homeostasis of the electrolytes and trace elements themself (7). The studies in the literature are numerous and basically connected to the establishment of their plasma levels. There are few reports on the intracellular and especially intraerythrocytes concentrations of trace elements and $\mathrm{Mg}$ $(7,8,9)$. It's supposed that the needs of protective agents (vitamines, minerals) against the degenerative processes in elderly are higher.

Del Corso et al (7) have determined blood concentrations of $\mathrm{Cu}, \mathrm{Zn}$ and $\mathrm{Mg}$. Their results sugest that the healthy free-living elderly have had an adequate mineral intake and don't need nutrient supplements. They may be useful in the elderly with chronic diseases.

Actually, Wakamoto et al. (12) have found higher serum concentrations of trace elements in $>85$ years, especially of phosphorus and Zn.

Our studied healthy elderly subjects over 80 years have normal plasma and $\mathrm{RBC} \mathrm{Mg}$, i.e. they have not Mg-detlciency. They haven't taken medicines that cause hypo- and hyper-Mg and have no data for $\mathrm{Mg}$ resorption disturbances and probably these two reasons explain our results.

The elderly are a risk group for Zn-deficiency. The risk for hypozincemia increases with aging (10). Prasad et al (1) has established a low intake of $\mathrm{Zn}$ with food in elderly. In our studied subjects plasma $\mathrm{Zn}$ is in normal range but trends to decrease, while RBC Zn level in elderly is lower than subjects in control group and it points possibly the proper active status of this trace element.

Opposite to $\mathrm{Zn}$, plasma $\mathrm{Cu}$ in elderly over 75 years is increased and correlates with the age (2). In case of insufficient feeding there is a great decreasing of plasma $\mathrm{Cu}(11)$. In our healthy elderly the tendency of increasing $\mathrm{RBC} \mathrm{Cu}$ with aging is underlined. On the other hand, the study of $\mathrm{RBC} \mathrm{Cu}$ demonstrates the opposite trend - decreasing with age.

\section{CONCLUSION}

In conclusion, the study of plasma $\mathrm{Cu}, \mathrm{Zn}$ and $\mathrm{Mg}$ in healthy elderly gives the possibility of assessment if aging influences electrolytes' and trace elements' homeostasis. Their misbalance in the organism can't be disguised early because the minimal plasma concentration of trace elements. If we have in mind their intensive action in the cellular processes, the examination of their RBC level allows a correct clinical evaluation of their metabolic status.

In the studied healthy elderly over 80 years we established normal plasma and $\mathrm{RBC} \mathrm{Mg}$. The plasma concentration of $\mathrm{Zn}$ was in the normal range but trended towards decreasing. RBC $\mathrm{Zn}$ in elderly over 80 years was significantly decreased in comparison to the control group and showed $\mathrm{Zn}$-deficiency in these subjects. Plasma $\mathrm{Cu}$ increased with aging (significantly over 90 years), while $\mathrm{RBC} \mathrm{Cu}$ showed a tendency of decreasing (significantly at the age 80-89 years).

In our study the elderly individuals are clinically healthy subjects. They haven't any data for disease or medication, which would provoke deficiency. It's possible that the established results are due to aging itself or to disbalanced feeding. For this reason, we accept that even in healthy elderly over 80 years it's necessary to enrich the food with $\mathrm{Zn}$.

\section{REFERENCE}

1. Prasad AS. Fitzgerald JT \& al. Zinc defficiency in elderly patients. Nutrition 1993; 9 (3): 218-224 
2. Madric A, Ginter E, Kadrabova J. Serum copper, zinc and copper-zinc ratio in males: influence of aging. Physiol.Res 1994; 43 (2): 107-1 11.

3. Seeling MS, Preuss HG. Magnesium metabolism and perturbation in the elderly. Geriatric Nephrology and Urology 1994; vol.4: 101-111

4. Paskalev D. Chronic hemodialysis and rhEPO treatment: some effects on the organism, free radical reactions, antioxidant system and electrolytes in RBC. RhD -Thesis, Varna 1994

5. Burdmaim E A, Andoh TF, Lidsley J et al. Effects of oral magnesium supplementation on acute experimental cyclosporin nephrotoxicity. Nephrol Dial Transplant 1994; vol.9: 16-21

6. Robert W, Siebers L, Timothy J, Mating B. Flame photometry: a simple method and reference range for erythrocyte sodium and potassium. Medical Laboratory Sci 1988; vol 45: 270-272

7. Del Corso L, Pastine F, Protti MA, Romanelli AM, Moruzzo D, Ruocco L \& al. Blood zinc, copper and magnesium in aging. A study in healthy home-living elderly. Panminerva Med 2000 Dec; 42 (4): 273 - 277
8. Prohaska C, Pomazal K, Steffan I. Determination of $\mathrm{Ca}, \mathrm{Mg}, \mathrm{Fe}, \mathrm{Cu}$, and $\mathrm{Zn}$ in blood fractions and whole blood of humans by JCP-OES. Fresenius $J$ Anal Chem 2000 Jul; 367 (5): 479 - 484

9. Kruse-Jarres JD, Rukgauer M. Trace elements in diabetes mellitus. Peculiarities and clinical validity of determinations in blood cells. J Trace Elem Med Biol 2000 Apr; 14 (1): 21-27

10. Savarino L, Granchi D, Ciapetti G \& al. Serum concentrations of zinc and selenium in elderly people: results in healthy nonagenarians/centenarians. Exp Gerontol 2001 Feb; 36 (2): 327 -339

11. Banno S, Niita M, Kikuchi M \& al. Anaemia and neutropenia in elderly patients caused by deficiency for long-term enteral nutrition. Jap J Clin Hematol 1994; 35 (11): 1276 -1281.

12. Wakamoto Y, Aramaki T, Okuda M \& al. Comparison of serum concentrations of trace elements in healthy free-living and hospitalized oldest-old. Nippon Koshu Eisei Zasshi 2002 Feb; 49 (2): 106-1 13 